\title{
Experimental transmission and tissue tropism of Macrobrachium rosenbergii nodavirus (MrNV) and its associated extra small virus (XSV)
}

\author{
A. S. Sahul Hameed ${ }^{1, *}$, K. Yoganandhan ${ }^{1}$, J. Sri Widada ${ }^{2}$, J. R. Bonami ${ }^{2}$ \\ ${ }^{1}$ Department of Zoology, C. Abdul Hakeem College, Melvisharam 632 509, Vellore District, Tamil Nadu, India \\ ${ }^{2}$ Pathogens and Immunity, CNRS/UM II, Universite Montpellier II, Case 080, Place Eugene Bataillon, \\ 34095 Montpellier Cedex 5, France
}

\begin{abstract}
White tail disease (WTD) was found to be a serious problem in hatcheries and nursery ponds of Macrobrachium rosenbergii in India. The causative organisms have been identified as $M$. rosenbergii nodavirus ( $M r N V$ ) and its associated extra small virus (XSV). Experimentally transmitted to healthy animals, they caused $100 \%$ mortality in post-larvae but failed to cause mortality in adult prawns. The RT-PCR assay revealed the presence of both viruses in moribund post-larvae and in gill tissue, head muscle, stomach, intestine, heart, hemolymph, pleopods, ovaries and tail muscle, but not in eyestalks or the hepatopancreas of experimentally infected adult prawns. The presence of these viruses in ovarian tissue indicates the possibility of vertical transmission. Pleopods have been found to be a suitable organ for detecting these viruses in brooders using the RT-PCR technique.
\end{abstract}

KEY WORDS: Macrobrachium rosenbergii · Macrobrachium rosenbergii nodavirus · RT-PCR · Pathogenicity $\cdot$ Tissue tropism

Resale or republication not permitted without written consent of the publisher

\section{INTRODUCTION}

Macrobrachium rosenbergii is the most important cultured palaemonid in the world, and it is now farmed on a large scale in many countries, including India. There is tremendous scope for development of freshwater prawn culture in India, where total production has increased significantly, reaching an all time high of 20000 metric tons in 2002. Threatening this success, a new disease, similar to white tail disease (WTD) first reported from the French West Indies by Arcier et al. (1999), has been observed in hatcheries and nursery ponds located in Andhra Pradesh and Tamil Nadu. This has caused mortality up to $100 \%$ within 2 or $3 \mathrm{~d}$. The loss so far has been estimated to be several million dollars, and it continues to grow (Sahul Hameed et al. 2004). It has caused high economic loss in the West Indies since 1994. WTD has also been reported in Taiwan (Tung et al. 1999) and China (Qian et al. 2003).
Other serious diseases associated with white tails have been reported in freshwater prawns (AQUACOP 1977, Anderson et al. 1990, Cheng \& Chen 1998, Tung et al. 1999, Qian et al. 2002). Anderson et al. (1990) reported a parvo-like virus responsible for mass mortality in a freshwater prawn hatchery. Macrobrachium muscle virus (MMV) was reported by Tung et al. (1999) and found to be responsible for high mortalities in hatchery-reared M. rosenbergii. Cheng \& Chen (1998) reported an Enterococcus-like bacterium that caused muscle necrosis of $M$. rosenbergii in Taiwan.

The causative agent of WTD has been identified as Macrobrachium rosenbergi nodavirus ( $M r N V)$. It is a small, icosahedral, non-enveloped particle, 26 to $27 \mathrm{~nm}$ in diameter, with a capsid that contains a single polypeptide of $43 \mathrm{kDa}$ (Romestand \& Bonami 2003). It is found in the cytoplasm of connective tissue cells and has been placed in the Nodaviridae family based on its characteristics and genome sequence (Garzon \& Char- 
pentier 1992, van Regenmortel et al. 2000, Romestand \& Bonami 2003). The pathogen responsible for WTD in India has also been identified as $M r N V$, as it has in Taiwan and China, by the RT-PCR technique using primers based on the sequence of MrNV-RNA at GenBank (Arcier et al. 1999, Qian et al. 2003, Sri Widada et al. 2003).

Although the gross sign of whitish tail muscle is the main sign used to diagnose WTD, it is not specific to WTD, as described above. Hence, some sensitive and specific diagnostic methods were urgently needed to detect $\mathrm{MrNV}$ in its early stages. A sandwich enzymelinked immunosorbent assay was first developed using antibodies raised against $\mathrm{MrNV}$ (Romestand \& Bonami 2003). Three detection methods based on specific nucleic acid probes and primer were subsequently developed (Sri Widada et al. 2003), and RT-PCR has been proven to be the most sensitive method of detection.

Recently, Qian et al. (2003) have reported the occurrence of an additional virus to $\mathrm{MrNV}$ that may also be responsible for WTD in prawns from China. This virus is smaller in diameter (14 to $16 \mathrm{~nm}$ ) than $M r N V$ and appears to be 5 or 6 sided when viewed using transmission electron microscopy (TEM). Because of its unusually small size, it has been designated an extra small virus (XSV) (Qian et al. 2003). Its genome consists of 1 linear, single-stranded RNA fragment that has been fully sequenced, and an RT-PCR method has been developed to detect it (Sri Widada et al. 2004).

In the present study, pathogenicity and tissue and organ distribution of these 2 viruses was examined in experimentally infected post-larvae and adult freshwater prawns using RT-PCR assay.

\section{MATERIALS AND METHODS}

Collection of infected post-larvae. Infected post-larvae (PL) with prominent signs of whitish muscle in the abdominal region were collected from hatcheries located near Nellore, Andhra Pradesh, and Chennai, Tamil Nadu, India. The PL were washed in sterile saline solution, transferred to sterile tubes for transport to the laboratory on dry ice and then stored at $-20^{\circ} \mathrm{C}$. The physicochemical characteristics of hatchery and nursery pond water and percentage mortality were determined for each sampling of infected animals. Dissolved oxygen, salinity, $\mathrm{pH}$ and temperature were measured. Salinity was measured with a salinometer and dissolved oxygen was estimated using the Winkler method (Strickland \& Parsons 1968).

Preparation of viral inoculum. Frozen infected PL were thawed and homogenized in a sterile homogenizer. A $10 \%(\mathrm{w} / \mathrm{v})$ suspension was made with TN buffer (20 mM Tris- $\mathrm{HCl}$ and $0.4 \mathrm{M} \mathrm{NaCl}, \mathrm{pH}$ 7.4). The homogenate was centrifuged at $4000 \times g$ for $20 \mathrm{~min}$ at $4^{\circ} \mathrm{C}$ and its supernatant was recentrifuged at $10000 \times g$ for $20 \mathrm{~min}$ at $4^{\circ} \mathrm{C}$ before the final supernatant was filtered through a $0.22 \mu \mathrm{m}$ pore membrane. The filtrate was then stored at $-20^{\circ} \mathrm{C}$ for infectivity studies.

Collection and maintenance of experimental animals. For experimental transmission, healthy PL (10) were colleted from a hatchery in a locality with no record of WTD. They were randomly sampled and screened for WTD by RT-PCR assay prior to challenge experiments. After collection, the PL were washed with sterile freshwater to remove food and other materials adhering to the body. The washed PL were maintained in glass aquaria (25 l) containing aerated freshwater at a temperature of 27 to $30^{\circ} \mathrm{C}$ and fed twice a day with Artemia nauplii. Healthy adult prawns (30 to $50 \mathrm{~g}$ body weight) were collected from grow-out ponds located near Nellore and maintained in $1000 \mathrm{l}$ fiberglass tanks with continuous aeration at room temperature $\left(27\right.$ to $\left.30^{\circ} \mathrm{C}\right)$ in freshwater. The animals were fed with commercial pellet feed (CP shrimp feed, Thailand).

Infectivity experiments. The experimental pathogenicity of $M r N V$ and XSV to healthy PL and adult prawns of Macrobrachium rosenbergii was carried out by immersion challenge and intramuscular injection, respectively. In the immersion challenge, the PL were placed (50 ind. $\mathrm{l}^{-1}$ ) in beakers (5 l) containing freshwater with continuous aeration. The beakers were covered to prevent contamination. The PL were fed with Artemia nauplii. The viral inoculum (MrNV and $\mathrm{XSV}$ ) was added to water at a volume equal to $0.1 \%$ of the total rearing medium $\left(1 \mathrm{ml} \mathrm{l}^{-1}\right)$ (Venegas et al. 1999, Chen et al. 2000). Control groups were exposed to tissue filtrates $(0.1 \%)$ prepared from healthy PL. The experiment was conducted in triplicate.

Adult prawns were infected by intramuscular injection of $M r N V$ and XSV. They were maintained in fiberglass tanks (10 per tank) at room temperature containing freshwater with continuous aeration. The experimental animals were injected intramuscularly in the second abdominal segment with filtrate $(50 \mu \mathrm{l}$ ind. ${ }^{-1}$ ) prepared from infected PL using $1 \mathrm{ml}$ insulin syringes. Control animals were injected with the filtrate prepared from healthy PL.

The experimental prawns were examined twice per day for gross signs of disease, and the number of deaths was recorded so that cumulative percentage mortality could be calculated.

Total RNA extraction. For extraction of total RNA, $150 \mathrm{mg}$ of whole PL or pieces of different organs (gill tissue, hepatopancreas, heart, stomach, eyestalks, head muscle, abdominal muscle, tail muscle, ovary, intestines and pleopods) or hemolymph $(150 \mu l)$ from 
adult prawns were homogenized in $300 \mu$ of TN buffer (20 mM Tris-HCl, 0.4 M NaCl, pH 7.4). The homogenate was centrifuged at $12000 \times g$ for $15 \mathrm{~min}$ at room temperature. The supernatant was collected and referred to as crude tissue extract. Total RNA was extracted using TRIzol reagent (GIBCO-BRL) according to the protocol of the manufacturer. Briefly, $1 \mathrm{ml}$ of TRIzol reagent was added to $150 \mu l$ of crude tissue extract and homogenized. After $5 \mathrm{~min}$ of incubation at room temperature, $0.2 \mathrm{ml}$ of chloroform was added. The sample was vigorously shaken for 2 to $3 \mathrm{~min}$ at room temperature then centrifuged at $12000 \times g$ for $15 \mathrm{~min}$ at room temperature. RNA was precipitated from the aqueous phase with isopropanol, washed with $75 \%$ ethanol and dissolved in $50 \mu \mathrm{l}$ of TE buffer (10 mM Tris-HCl, 1 mM EDTA, pH 7.5). The amount of nucleic acid in the sample was quantified by measuring the absorbance at $260 \mathrm{~nm}$. The purity of the preparation was checked by measuring the ratio of optical density $\mathrm{OD}_{260 \mathrm{~nm}} / \mathrm{OD}_{280 \mathrm{~nm}}$.

RT-PCR for MrNV and XSV. RT-PCR was carried out using the Reverse-IT ${ }^{\mathrm{TM}}$ 1-step RT-PCR kit (ABgene), allowing reverse transcription (RT) and amplification to be performed in a single reaction tube. One pair of primers specific to $M r N V-R N A 2$ was designed from sequence data of the MrNV genome (GenBank Accession No. AY222840). The sequences were 5' GCG TTA TAG ATG GCA CAA GG 3' (forward) and 5' AGC TGT GAA ACT TCC ACT GG 3' (reverse) (Sahul Hameed et al. 2004). The size of the DNA amplicon was $425 \mathrm{bp}$. Reactions were performed in $50 \mu \mathrm{l}$ RT-PCR buffer containing 20 pmol of each primer and RNA template, using the following steps: $\mathrm{RT}$ at $52^{\circ} \mathrm{C}$ for $30 \mathrm{~min}$; denaturation at $95^{\circ} \mathrm{C}$ for 2 min followed by 30 cycles of denaturation at $94^{\circ} \mathrm{C}$ for $40 \mathrm{~s}$, annealing at $55^{\circ} \mathrm{C}$ for $40 \mathrm{~s}$ and elongation at $68^{\circ} \mathrm{C}$ for $1 \mathrm{~min}$, ending with an additional elongation step of $10 \mathrm{~min}$ at $68^{\circ} \mathrm{C}$. For XSV detection, the primers were 5' GGA GAA CCA TGA GAT CAC G 3' (forward) and 5' CTG CTC ATT ACT GTT CGG AGT C 3' (reverse) (Sri Widada et al. 2004). The amplification product was $500 \mathrm{bp}$. The reaction conditions were similar to those for MrNV. The RTPCR products $(10 \mu \mathrm{l})$ were then analyzed by electrophoresis on a $0.8 \%$ agarose gel.

\section{RESULTS}

The viral inoculum used in the experimental infections was prepared from PL with gross signs of whitish tails, and the presence of $M r N V$ and XSV in the inoculum was confirmed by RT-PCR. The cumulative percentage mortality in PL exposed to $\mathrm{MrNV}$ and XSV is shown in Fig. 1. Three dilutions of viral suspension were used and mortality was observed at all dilutions.

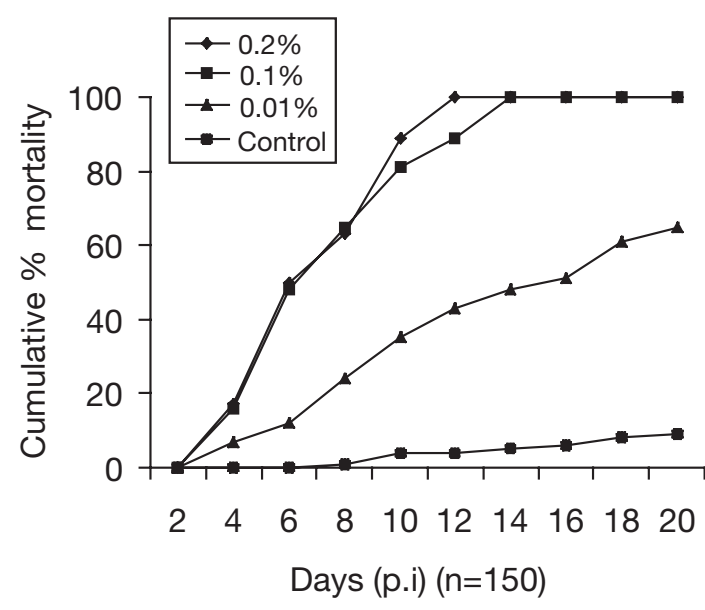

Fig. 1. Macrobrachium rosenbergii. Experimentally induced pathogenicity of $\mathrm{MrNV}$ and XSV in post-larvae. Cumulative percent mortality was recorded every $2 \mathrm{~d}$ post-infection (p.i.) for groups of post-larvae which were immersed in $0.2,0.1$, and $0.01 \%$ virus suspension, and for a control group which was immersed in tissue extract prepared from healthy post-larvae

The 0.2 and $0.1 \%$ viral suspensions caused $100 \%$ mortality at 12 and $14 \mathrm{~d}$ post-challenge (dpc), respectively. The $0.01 \%$ viral suspension caused $65 \%$ mortality at 20 dpc. Clinical signs observed in the experimentally infected animals were similar to those seen in natural infections. These included lethargy, anorexia and opaqueness of abdominal muscle (whitish muscle). This opaqueness gradually expanded on both sides (anterior and posterior) and the telson and uropods degenerated in severe cases. Some live, infected PL without uropods were also observed. The gross sign of whitish muscle was observed in all moribund animals collected after 6 d post-infection but not before. The experimentally infected PL tested positive for $\mathrm{MrNV}$ and XSV by RT-PCR from 2 d post-infection onwards (Fig. 2).

These 2 viruses failed to cause mortality or clinical signs of disease in injected adult prawns during the experimental period of $30 \mathrm{~d}$. However, RT-PCR analysis showed the appearance of prominent bands for MrNV (425 bp) and XSV (500 bp) in all the organs except in the hepatopancreas and eyestalks (Fig. 3). The intensity of the band in the case of $M r N V$ differed from organ to organ, whereas that for XSV was very prominent in all positive organs.

\section{DISCUSSION}

As with Sri Widada et al. (2003), who reported 2 types of virus particles ( $\mathrm{MrNV}$ and XSV) associated with WTD from China, we found both viruses using 

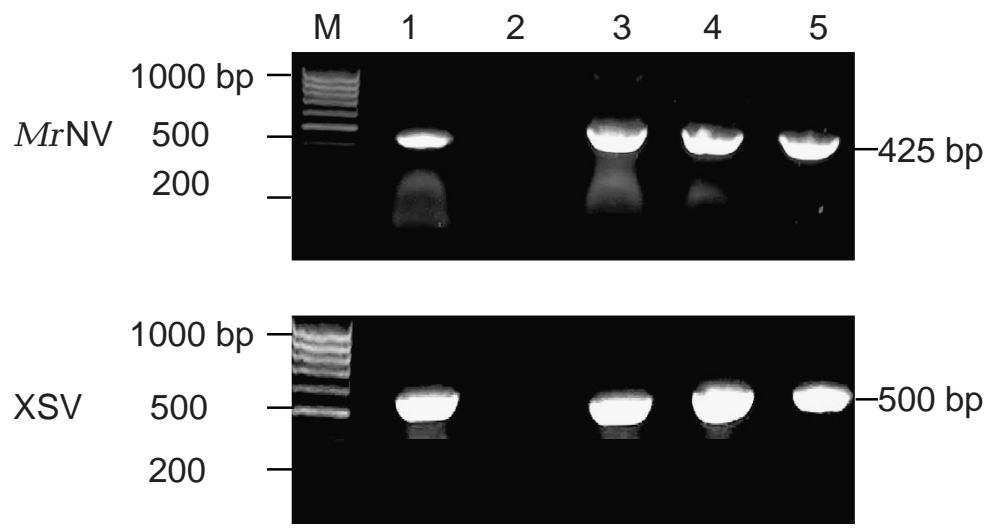
experimentally infected post-larvae. M: marker; Lane 1: virus suspention prepared from infected post-larvae; Lane 2: healthy post-larvae; Lanes 3, 4 and 5: different groups of post-larvae exposed to $\mathrm{MrNV}$ and XSV
Fig. 2. Macrobrachium rosenbergii. RT-PCR detection of MrNV and XSV in

defenses than in PL. Variation in mortality and disease susceptibility with age has been reported. For example, Gacutan et al. (1979) reported decreased susceptibility to Epheota infection in larvae of Penaeus monodon with age, and Lightner (1975) observed that $P$. seliferus seemed to be resistant to Lagenidium callinectes infection from the mysis stage onwards. The rapid propagation of larval necrosis caused by bacteria in zoea of penaeids and the young stages of $M$. rosenbergii showed that age is certainly an important factor in sensitivity to disease (AQUACOP 1977). A similar type of resistance against white spot syndrome virus (WSSV) has been observed in adult $M$. rosenbergii (Sahul Hameed et al. 2000), although the larvae can suffer mortality from it (Peng et al.

RT-PCR with WTD samples collected from Indian hatcheries. The presence of $>1$ virus in crustacean diseases has previously been reported (Bonami 1980, Mari 1987). It has been suggested that the occurrence of viral synergic actions might be due to the lack of an interferon-like reaction in invertebrates (Tanada 1956, Odier 1974). Since XSV is always found associated with the larger virus (nodavirus) and located in muscle and connective cells of infected prawns, it could be an autonomous virus, a helper-type virus or a satellite-like virus (Qian et al. 2003).

The experimental transmission of $M r N V$ and XSV resulting in high mortality and clinical signs of WTD in PL confirmed River's postulate (Iwanowicz \& Goodwin 2002) and implicated one or both of these viruses as being responsible for WTD in Macrobrachium rosenbergii. However, the fact that the same virus suspension caused mortality in PL but not in adult prawns was curious, especially since most tissues and organs of the adults did become infected with both viruses. It is possible that the adults resisted disease due to better
1998). The mechanism of adult resistance to $M r N V$ and XSV is not known. Disease resistance in some invertebrates is related to the production of bactericidins, lysins and agglutinins following exposure to foreign proteins (Bang 1967, McKay \& Jenkin 1969). It is possible that similar substances may account for the resistance of adult prawns to $\mathrm{MrNV}$ and XSV.

We found $M r N V$ and XSV in all the organs except eyestalks and the hepatopancreas of adult Macrobrachium rosenbergii. This was consistent with the results of Sri Widada et al. (2003), but not with those of Arcier et al. (1999), who also observed positive tests for $\mathrm{MrNV}$ in the hepatopancreas. The reason for this discrepancy is unknown. Knowing pathogen distribution in tissues and organs can help us to understand issues related to disease susceptibility and transmission and to choose optimal samples for pathogen isolation and detection, especially for potential carriers that may require monitoring for control measures. Tissue tropism of WSSV and yellow head virus has been studied by various workers (Lu et al. 1995, Lo et al. 1997, Sahul

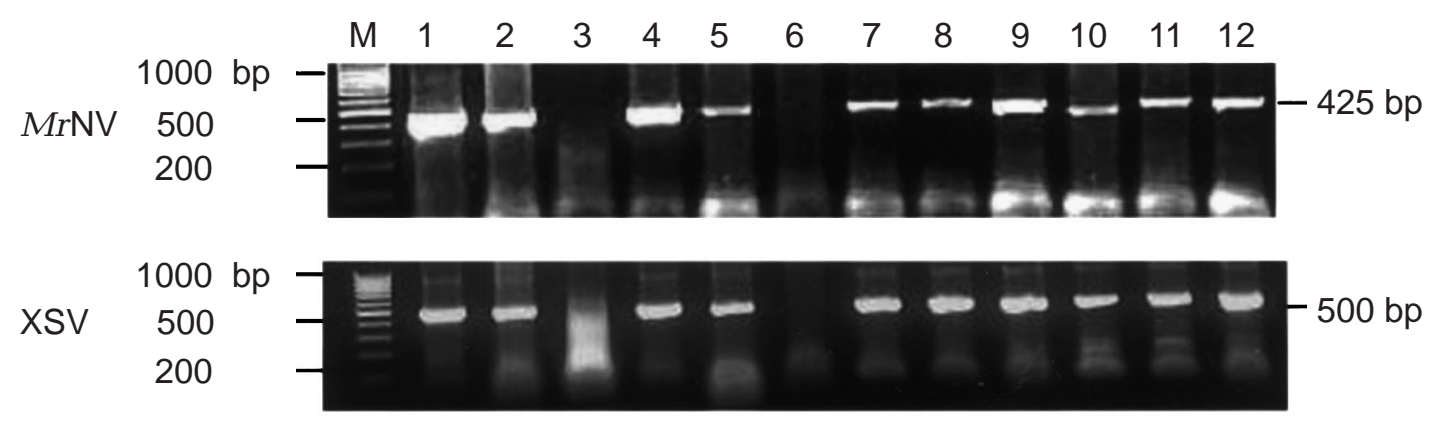

Fig. 3. Macrobrachium rosenbergii. RT-PCR detection of $M r N V$ and XSV in different organs of experimentally infected adult prawns. M: marker; Lane 1: hemolymph; Lane 2: gill tissue; Lane 3: hepatopancreas; Lane 4: heart; Lane 5: stomach; Lane 6: eyestalk; Lane 7: head muscle; Lane 8: abdominal muscle; Lane 9: tail muscle; Lane 10: ovarian tissue; Lane 11: intestine; Lane 12: pleopod 
Hameed et al. 1998) and has proven useful in discovering and closing transmission routes (Lo et al. 1997).

Finding both $\mathrm{MrNV}$ and XSV in all positive tissues and organs indicated that the 2 viruses were closely associated, and suggested that they might be mutually dependent as proposed by Qian et al. (2003). The fact that both viruses were present in ovarian tissue indicates the possibility of vertical transmission of WTD from brooders to larvae and PL. Because of this, we recommend the screening of brooders before they are allowed to spawn in hatcheries. For this purpose, our results on tissue distribution indicate that pleopods would be a convenient source of RNA for non-destructive screening of $M r N V$ and XSV without stress to the prawns.

Acknowledgements. The authors thank the management of C. Abdul Hakeem College, Melvisharam, India, for providing the facilities to carry out this work. This study was funded by a grant from the Indian Council of Agricultural Research (ICAR), New Delhi, India.

\section{LITERATURE CITED}

Anderson IG, Law AT, Sharrif M, Nash G (1990) A parvo-like virus in the giant freshwater prawn, Macrobrachium rosenbergii. J Invert Pathol 55:447-449

AQUACOP (1977) Observation on diseases of crustacean culture in Polynesia. Proc World Mariculture Soc 8: 685-703

Arcier JM, Herman F, Lightner DV, Redman R, Mari J, Bonami JR (1999) A viral disease associated with mortalities in hatchery-reared postlarvae of the giant freshwater prawn Macrobrachium rosenbergii. Dis Aquat Org 38: 177-181

Bang FB (1967) Serological responses among invertebrates other than insects. Federation Proc 267:1680-1684

Bonami JR (1980) Recherches sur les infections virales des crustacés marins: étude des maladies à ôtiologie simple et complexe chez les Décapodes des côtes françaises. PhD thesis, Université des Sciences et Techniques du Languedoc, Montpellier 2

Chen LL, Lo CF, Chiu YL, Chang CF, Kou GH (2000) Natural and experimental infection of white spot syndrome virus WSSV in benthic larvae of mud crab Scylla serrata. Dis Aquat Org 40:157-161

Cheng W, Chen JC (1998) Isolation and characterization of an Enterococcus-like bacterium causing muscle necrosis and mortality in Macrobrachium rosenbergii in Taiwan. Dis Aquat Org 34:93-101

Gacutan RG, Llobrera AT, Santigo CB, Gutierrez PJ, Po GL (1979) A suctorean parasite of Penaeus monodon larvae. In: Proc Biennial Crustacean Health Workshop, Sea Grand Publ TAMU-SG-79-114, Texas A \& M University, College Station, TX, p 202-213

Garzon S, Charpentier G (1992) Nodaviridae. In: Adams JR, Bonami JR (eds) Atlas of invertebrate viruses. CRC Press, Boca Raton, FL, p 351-370

Iwanowicz LR, Goodwin AE (2002) A new bacilliform fathead minnow rhabdovirus that produces syncytia in tissue culture. Arch Virol 147(5):899-915

Lightner DV (1975) Some potential serious disease problems in the culture of penaeid shrimp in North America. Spec Publ Fishery Agency, Japanese Government and Japan Sea Regional Research Laboratory, Niigata, p 75-97

Lo $\mathrm{CF}$, Ho CH, Chen $\mathrm{CH}$, Liu KF and 9 others (1997) Detection and tissue tropism of white spot syndrome baculovirus (WSSV) in captured brooders of Penaeus monodon with special emphasis on reproductive organs. Dis Aquat Org 30:53-72

Lu Y, Tapay LM, Loh PC, Brock JA, Gose RB (1995) Distribution of yellow-head virus in selected tissues and organs of penaeid shrimp Penaeus vannamei. Dis Aquat Org 23: $67-70$

Mari J (1987) Recherches sur les maladies virales du Crustacé Décapode marin Carcinus mediterraneus Czerniavsky 1884. PhD thesis, Université de Montpellier 2

Mckay D, Jenkin CR (1969) Immunity in invertebrates: II. Adaptive immunity in the cray fish Parachaeraps bicarinatus. Immunology 17:127-137

Odier F (1974) Mise en évidence et étude d'un complexe de maladies à parvovirus, baculovirus et iridovirus. Entomophaga 22:397-404

Peng SE, Lo CF, Ho CH, Chang CF, Kou GH (1998) Detection of white spot baculovirus (WSBV) in giant freshwater prawn, Macrobrachium rosenbergii, using polymerase chain reaction. Aquaculture 164:253-262

Qian D, Shi Z, Zhang S, Cao Z and 5 others (2003) Extra small virus-like particles (XSV) and nodavirus associated with whitish muscle disease in the giant freshwater prawn, Macrobrachium rosenbergii. J Fish Dis 26:521-527

Qian F, Yang G, Liu W, Wang J, Cao Z (2002) Preliminary studies on whitish muscle disease of Macrobrachium rosenbergii post-larvae. Acta Hydrobiol Sin 26:472-476

Romestand B, Bonami JR (2003) A sandwich enzyme linked immunosorbent assay (S-ELISA) for detection of $M r N V$ in the giant freshwater prawn, Macrobrachium rosenbergii (de Man.). J Fish Dis 26:71-75

Sahul Hameed AS, Anilkumar M, Stephen Raj ML, Kunthala J (1998) Studies on the pathogenicity of systemic ectodermal and mesodermal baculovirus and its detection in shrimp by immunological methods. Aquaculture 160: $31-45$

Sahul Hameed AS, Xavier Charles M, Anilkumar M (2000) Tolerance of Macrobrachium rosenbergii to white spot syndrome virus. Aquaculture 183:207-213

Sahul Hameed AS, Yoganandhan K, Sri Widada J, Bonami JR (2004) Studies on the occurrence of Macrobrachium rosenbergii nodavirus and extra small virus-like particles associated with white tail disease of $M$. rosenbergii in India by RT-PCR detection. Aquaculture 238:127-133

Sri Widada, J Durand S, Cambournac, Qian D, Shi Z, Dejonghe E, Richard V, Bonami JR (2003) Genome-based detection methods of Macrobrachium rosenbergii nodavirus, a pathogen of the giant freshwater prawn, Macrobrachium rosenbergii: dot-blot, in situ hybridization and RT-PCR. J Fish Dis 26:583 -590

Sri Widada J, Richard V, Shi Z, Qian D, Bonami JR (2004) Dot-blot hybridization and RT-PCR detection of extra small virus (XSV) associated with white tail disease of prawn Macrobrachium rosenbergii. Dis Aquat Org 58: 83-87

Strickland JDH, Parsons TR (1968) A practical handbook of water analysis. Bull Fish Res Board Can 167

Tanada Y (1956) Some factors affecting the susceptibility of the armyworms to virus infections. J Econ Entomol 49: $52-57$

Tung CW, Wang CS, Chen SN (1999) Histological and electron microscopic study on Macrobrachium muscle virus 
(MMV) infection in the giant freshwater prawn, Macrobrachium rosenbergii (de Man), cultured in Taiwan. J Fish Dis $22: 1-5$

van Regenmortel MHV, Fauquet CM, Bishop DHL, Cartens EB and 7 others (2000) Virus taxonomy: classification and nomenclature of viruses. Seventh Report of the Inter-

Editorial responsibility: Timothy Flegel, Bangkok, Thailand national Committee on Taxonomy of Viruses. Academic Press, San Diego, CA

Venegas CA, Nonaka L, Mushiake K, Nishizawa T, Muroga K (1999) Pathogenicity of penaeid rod-shaped DNA virus PRDV to kuruma prawn at different development stages. Fish Pathol 170:179-194

Submitted: January 5, 2004; Accepted: September 3, 2004 Proofs received from author(s): November 17, 2004 